\title{
Cerebrospinal Fluid Protein Biomarkers for Alzheimer's Disease
}

\author{
Kaj Blennow \\ Department of Clinical Neuroscience, Section of Experimental Neuroscience, The Sahlgrenska Academy at Göteborg University, \\ SE-43180 Göteborg, Sweden
}

\begin{abstract}
Summary: The introduction of acetylcholine esterase (AChE) inhibitors as a symptomatic treatment of Alzheimer's disease (AD) has made patients seek medical advice at an earlier stage of the disease. This has highlighted the importance of diagnostic markers for early AD. However, there is no clinical method to determine which of the patients with mild cognitive impairment (MCI) will progress to AD with dementia, and which have a benign form of MCI without progression. In this paper, the performance of cerebrospinal fluid (CSF) protein biomarkers for $\mathrm{AD}$ is reviewed. The diagnostic performance of the three biomarkers, total tau, phospho-tau, and the 42 amino acid form of $\beta$-amyloid have been evaluated in numerous studies and their ability to identify incipient AD in MCI cases has also been studied. Some candidate AD biomarkers including ubiquitin, neurofilament proteins, growth-associated protein 43
\end{abstract}

(neuromodulin), and neuronal thread protein (AD7c) show interesting results but have been less extensively studied. It is concluded that CSF biomarkers may have clinical utility in the differentiation between $\mathrm{AD}$ and several important differential diagnoses, including normal aging, depression, alcohol dementia, and Parkinson's disease, and also in the identification of Creutzfeldt-Jakob disease in cases with rapidly progressive dementia. Early diagnosis of AD is not only of importance to be able to initiate symptomatic treatment with $\mathrm{AChE}$ inhibitors, but will be the basis for initiation of treatment with drugs aimed at slowing down or arresting the degenerative process, such as $\gamma$-secretase inhibitors, if these prove to affect AD pathology and to have a clinical effect. Key Words: Alzheimer's disease, cerebrospinal fluid, biomarker, tau, phosphorylated tau, $\beta$-amyloid.

\section{ALZHEIMER'S DISEASE}

Alzheimer's disease (AD) is the most common form of dementia. There are exceptional cases with the familial (autosomal dominant) form of $\mathrm{AD}$, but the large majority of patients have the sporadic form of the disease. ${ }^{1}$ The characteristic findings at the microscopic level are degeneration of the neurons and their synapses together with extensive amounts of senile plaques and neurofibrillary tangles. $^{2}$

During the preclinical phase of AD the neuronal degeneration proceeds and the amount of plaques and tangles increase and at a certain threshold the first symptoms, most often impairment of episodic memory, appear. This preclinical period probably starts 20-30 years before the first clinical symptoms appear. ${ }^{3}$

According to current diagnostic criteria, ${ }^{4} \mathrm{AD}$ cannot be diagnosed clinically before the disease has progressed

Address correspondence and reprint requests to Kaj Blennow, M.D., Ph.D., Department of Clinical Neuroscience, Section of Experimental Neuroscience, The Sahlgrenska Academy at Göteborg University, Sahlgrenska University Hospital, SE-431 80 Mölndal, Sweden. E-mail: kaj.blennow@neuro.gu.se. so far that dementia is present. This means that the symptoms must be severe enough to significantly interfere with work and social activities or relations. In recent years, however, the clinical phase of $\mathrm{AD}$ with mild memory impairment but without overt dementia, called mild cognitive impairment (MCI), ${ }^{5}$ has attained increased attention in the medical community.

To make a diagnosis of MCI, memory disturbances should be "verified" by objective measures adjusted for age and education. ${ }^{5}$ However, like dementia, MCI may be caused by several different disorders. Many MCI patients have incipient $\mathrm{AD}$, i.e., they have early $\mathrm{AD}$ pathology and will progress to $\mathrm{AD}$ with dementia, whereas other $\mathrm{MCI}$ cases have a "benign" form of MCI as part of the normal aging process. ${ }^{6}$ Furthermore, in some MCI cases, cerebrovascular pathology (e.g., infarcts, white-matter lesions) may contribute to the symptoms. ${ }^{6}$

\section{THE IMPORTANCE OF DIAGNOSTIC MARKERS FOR AD AND MCI}

The introduction of acetylcholine esterase (AChE) inhibitors as symptomatic treatment has highlighted the importance of diagnostic markers for $\mathrm{AD}$. The awareness 
in the population of the availability of drug treatment has also made patients seek medical advice at an earlier stage of the disease, making the percentage of MCI cases at dementia clinics increase. This has increased the diagnostic challenge for physicians, because the characteristic clinical picture of $\mathrm{AD}$ with slowly progressive memory disturbances combined with parietal lobe symptoms ${ }^{7}$ has not yet developed in MCI cases. Accordingly, there is no clinical method to determine which MCI cases will progress to $\mathrm{AD}$ with dementia except for a very long clinical follow-up period.

Thus, new diagnostic tools to aid the diagnosis of early $\mathrm{AD}$ and to identify incipient $\mathrm{AD}$ in MCI cases would be of great importance. Such diagnostic markers would be of even higher significance if new drugs such as $\beta$-sheet breakers and $\beta$-secretase and $\gamma$-secretase inhibitors, with promise of disease-arresting effects, will prove to have clinical effect. Such drugs will probably be more effective in the earlier stages of the disease before neurodegeneration is too severe and widespread.

\section{THE BIOLOGICAL AND PATHOGENIC BASIS FOR AD BIOMARKERS IN CSF}

The cerebrospinal fluid (CSF) is in direct contact with the extracellular space of the brain. Therefore, biochemical changes in the brain are reflected in the CSF. Since $\mathrm{AD}$ pathology is restricted to the brain, CSF has been the focus in research on diagnostic biomarkers for $\mathrm{AD}$.

CSF biomarkers for AD should reflect the central pathogenic processes in the brain, i.e., the synaptic and axonal degeneration, the aggregation of $\beta$-amyloid $(\mathrm{A} \beta)$ with subsequent deposition in plaques, and the hyperphosphorylation and ubiquitination of tau with subsequent formation of tangles.

The three biomarkers, total tau (T-tau), phospho-tau (P-tau), and the 42 amino acid form of $\beta$-amyloid $(\mathrm{A} \beta 42)$, have been evaluated in numerous studies. Furthermore, their performance in the identification of incipient AD in MCI cases has also been examined. Lastly, there have been some longitudinal studies, also some performed in clinical practice. Therefore, these biomarkers are reviewed separately.

Some candidate AD protein biomarkers, including ubiquitin, neurofilament (NF) proteins, growth-associated protein 43 (GAP43) (neuromodulin) and neuronal thread protein (NTP) (AD7c), have been less extensively studied. These biomarkers are reviewed at the end of this paper.

\section{TAU AND $\beta$-AMYLOID AS BIOMARKERS FOR AD}

\section{Tau protein}

Tau is a microtubule-associated protein, primarily located in the neuronal axons. Because of alternative splic- ing of tau mRNA, there are six isoforms with 352-441 amino acids and with molecular weights between 50 and $65 \mathrm{kDa}^{8}$ By binding to tubulin in the axonal microtubules, tau promotes microtubule assembly and stability, ${ }^{8,9}$ which is important for axonal function and transport. Tau is a phosphoprotein, with more than 30 potential phosphorylation sites. ${ }^{9,10}$ The tangles in AD are made up of an abnormally hyperphosphorylated form of tau. ${ }^{11}$ Because of the hyperphosphorylation, tau also loses its ability to bind to the microtubules and to stimulate their assembly. ${ }^{12}$

CSF T-tau. As shown in Table 1, four different ELISA methods for quantification of T-tau have been published. ${ }^{13-16}$ A moderate to marked increase in CSF T-tau in $\mathrm{AD}$ has consistently been found in numerous publications. ${ }^{17}$

The first paper on CSF T-tau as a protein biomarker for AD used an ELISA method with a polyclonal reporter antibody and found a very marked increase in CSF T-tau in AD. ${ }^{13}$ Subsequent studies used ELISA methods ${ }^{14-16}$ based on monoclonal antibodies that detect all isoforms of tau independently of phosphorylation state, and found increases in CSF T-tau of approximately $300 \%$ and $200 \% .^{17}$

The CSF level of T-tau probably reflects the intensity of the neuronal damage and degeneration. This assumption is based on the findings that in acute conditions such as stroke, there is a marked transient increase in CSF T-tau that shows a correlation with computerized tomography measurements of infarct size. ${ }^{18}$ Furthermore, the highest increase in CSF T-tau is found in disorders with very intense neuronal degeneration, such as CreutzfeldtJakob disease (CJD), ${ }^{19}$ whereas a moderate to marked increase is found in $\mathrm{AD}$ with less intense degeneration, ${ }^{20}$ and normal levels are found in patients with depression, with limited or no degeneration. ${ }^{14}$

CSF P-tau. At least 30 phosphorylation sites have been identified on tau protein. ${ }^{9}$ Most of these are Ser-Pro or Thr-Pro motives and are localized outside the microtubule-binding domains. ${ }^{9}$ Hyperphosphorylation of tau is found during neuronal development and in several neurodegenerative disorders. ${ }^{9}{ }^{910}$ There is no consensus whether there are any phosphorylation sites that are specific for $\mathrm{AD}$ and thus not found in other tauopathies.

As shown in Table 1, six different ELISA methods have been developed for quantification of tau phosphorylated at different epitopes, including threonine $181+231,{ }^{14}$ threonine $181,{ }^{21}$ threonine $231+$ serine $235,{ }^{22}$ serine $199,,^{22}$ threonine $231,{ }^{23}$ and serine $396+404 .{ }^{24}$ A moderate to marked increase in CSF P-tau has been found using all of these different ELISA methods (Table 1).

The CSF level of P-tau probably reflects the phosphorylation state of tau. This hypothesis comes from indirect evidence such as the finding that there is no change in CSF P-tau after acute stroke, ${ }^{25}$ although there is a marked increase in T-tau. ${ }^{18}$ Furthermore, CSF P-tau lev- 
TABLE 1. Immunoassays for Cerebrospinal Fluid Total Tau, Phospho-Tau and $\beta$-Amyloid (Aß42)

\begin{tabular}{|c|c|c|c|c|}
\hline Type of Method & Ref. & Specificity & Antibodies & Mean Change ( $\%$ of controls) \\
\hline \multicolumn{5}{|l|}{ Total tau } \\
\hline ELISA & 13 & Total tau & $\mathrm{AT} 120+\mathrm{PAb}$ & Increase \\
\hline ELISA & 14 & Total tau & AT120 + HT7/BT2 & Increase $(\text { mean } \approx 300 \%)^{17}$ \\
\hline ELISA & 15 & Total tau & $16 \mathrm{~B} 5+16 \mathrm{G} 7$ & Increase $(\text { mean } \approx 200 \%)^{17}$ \\
\hline Microsphere ELISA & 16 & Total tau & PAb-ht2 + MAbs F-F11/F-H5 & Increase $(216 \%)$ \\
\hline \multicolumn{5}{|l|}{ Phospho-tau } \\
\hline ELISA & 14 & $\begin{array}{l}\text { P-Thr181 + } \\
\text { P-Thr231 }\end{array}$ & AT180/AT270 + HT7/AT120 & Increase $(348 \%)$ \\
\hline ELISA & 22 & $\begin{array}{l}\text { P-Thr231 + } \\
\text { P-Ser235 }\end{array}$ & MAb anti-tau + anti-PT231PS235 & $\begin{array}{l}\text { Increase (no mean level } \\
\text { given) }\end{array}$ \\
\hline ELISA & 22 & P-Ser199 & MAb anti-tau + anti-PS199 & Increase $(\approx 2-300 \%)^{86,93}$ \\
\hline ELISA & 23 & P-Thr231 & Tau1/CP27 + CP9 & Increase \\
\hline ELISA & 21 & P-Thr181 & $\mathrm{HT} 7+\mathrm{AT} 270$ & Increase $(\approx 2-300 \%)^{26,93}$ \\
\hline ELISA & 24 & $\begin{array}{c}\text { P-Ser396 + } \\
\text { P-Ser404 }\end{array}$ & PAb92e + PHF-1 & Increase $(346 \%)$ \\
\hline \multicolumn{5}{|l|}{$\beta$-amyloid } \\
\hline ELISA & 39 & $\mathrm{~A} \beta 1-42$ & BAN-50 + BC-05 & Decrease $(\text { mean } \approx 50 \%)^{17}$ \\
\hline ELISA & 41 & $\mathrm{~A} \beta 1-42$ & $21 \mathrm{~F} 12+3 \mathrm{D} 6$ & Decrease $(\text { mean } \approx 50 \%)^{17}$ \\
\hline ELISA & 35 & $\mathrm{~A} \beta \mathrm{X}-42$ & $266+$ PAb 277-2 & Decrease $(\text { mean } \approx 50 \%)^{17}$ \\
\hline ELISA & 39 & $\mathrm{~A} \beta \mathrm{X}-42$ & BNT-77 + BC-05 & Decrease $(\text { mean } \approx 50 \%)^{17}$ \\
\hline ELISA & 46 & $\mathrm{~A} \beta \mathrm{X}-42$ & $\mathrm{WO}-2+\mathrm{G} 2-11$ & Increase $(161 \%)$ \\
\hline ELISA & 42 & $\mathrm{~A} \beta \mathrm{X}-42$ & $6 \mathrm{E} 10+\mathrm{PAb} 164$ & Decrease $(32 \%)$ \\
\hline ELISA & 43 & $A \beta X-42$ & $4 \mathrm{G} 8+\mathrm{PAb} 44-344$ & Decrease $(37 \%)$ \\
\hline Western blot & 44 & $\mathrm{~A} \beta \mathrm{X}-42$ & G2-11 & Decrease $(43 \%)$ \\
\hline Immunoprecipitation + Western blot & 45 & $\mathrm{~A} \beta \mathrm{X}-42$ & G2-11 & Decrease $(39 \%)$ \\
\hline Urea SDS-PAGE + Western blot & 47 & $\mathrm{~A} \beta 1-42$ & n.a. & Decrease $(50 \%)$ \\
\hline SELDI-TOF & 48 & $\mathrm{~A} \beta 1-42$ & n.a. & Decrease $(71 \%)$ \\
\hline
\end{tabular}

Ref. $=$ reference number; $\mathrm{PAb}=$ polyclonal antibody $\mathrm{MAb}=$ monoclonal antibody; $\mathrm{Thr}=$ threonine; Ser $=$ serine; $\mathrm{n} . \mathrm{a} .=$ not applicable; SELDI-TOF = surface-enhanced laser desorption ionization time-of-flight masspectrometry.

els are normal or only mildly increased in CJD despite a very marked increase in T-tau. ${ }^{26}$ These data suggest that $\mathrm{P}$-tau in CSF is not simply a marker for neuronal degeneration or damage but that it specifically reflects the phosphorylation state of tau and thus possibly the formation of tangles in $\mathrm{AD}$ brain.

\section{$\boldsymbol{\beta}$-amyloid}

The main protein component of plaques is $\beta$-amyloid $(\mathrm{A} \beta),{ }^{27}$ which is generated by proteolytic cleavage of its precursor, the amyloid precursor protein (APP). ${ }^{28,29}$

Total A $\boldsymbol{\beta}$. After it was found that $\mathrm{A} \beta$ is generated as a soluble protein during normal cellular metabolism and is secreted to $\mathrm{CSF}^{30}{ }^{3}$ studies examining CSF $\mathrm{A} \beta$ as a candidate biomarker for $\mathrm{AD}$ were published. However, these initial reports on $\mathrm{A} \beta$ in CSF used ELISA methods for "total $\mathrm{A} \beta$ " that did not discriminate between different $\mathrm{A} \beta$ isoforms. Although some studies found a slight decrease in the $\mathrm{CSF}$ level of total $\mathrm{A} \beta$ in $\mathrm{AD},{ }^{31-33}$ there was a large overlap between $\mathrm{AD}$ patients and controls, and in other studies no change in CSF total $\mathrm{A} \beta$ in $\mathrm{AD}$ was found in $\mathrm{AD} .{ }^{34-36}$

A $\boldsymbol{\beta 4 2}$. There are several both N-terminally and Cterminally truncated forms of $\mathrm{A} \beta$. The two major $\mathrm{C}$ - terminal variants of $\mathrm{A} \beta$ consist of a shorter form ending at Val-40 (A $\beta 40)$, and a longer form ending at Ala-42 (A $\beta 42)$. $A \beta 42$ was found to aggregate more rapidly than $\mathrm{A} \beta 40,{ }^{37}$ and to be the initial and predominating form of $\mathrm{A} \beta$ deposited in diffuse plaques. ${ }^{38-40}$ These data made it logical to set focus on immunoassays specific for $\mathrm{A} \beta 42$.

As shown in Table 1, 11 different methods ${ }^{35,39,41-48}$ have been developed for quantification of $\mathrm{A} \beta 42$ in CSF. A moderate to marked decrease in CSF A $\beta 42$ in AD to about $50 \%$ of control levels has been found using the majority of these methods (Table 1). ${ }^{35,39,41-45,47,48}$ An increase in CSF $\mathrm{A} \beta 42$ in $\mathrm{AD}$ was found in one study. ${ }^{46}$ This finding may be attributable to methodological differences (e.g., assay specificity for aggregated or truncated $\mathrm{A} \beta$ variants). Alternatively, it may be due to differences in patient and control materials; in that study, increased CSF-A $\beta 42$ was also found in depression, ${ }^{46}$ whereas other studies have found normal CSF A $\beta 42$ levels in depression. ${ }^{49,50}$

The reduced CSF level of $\mathrm{A} \beta 42$ in $\mathrm{AD}$ is often hypothesized to be caused by deposition of $\mathrm{A} \beta 42$ in plaques, with lower levels diffusing to CSF. However, some studies have also found a marked reduction in CSF 
TABLE 2. Performance of CSF Total Tau as a Biomarker for Alzheimer's Disease

\begin{tabular}{|c|c|c|c|c|c|c|}
\hline $\begin{array}{l}\text { Study } \\
\text { Number }\end{array}$ & $\begin{array}{l}\text { Number of } \\
\text { AD Cases }\end{array}$ & $\begin{array}{c}\mathrm{AD} \\
\text { Sensitivity }\end{array}$ & $\begin{array}{l}\text { Number of } \\
\text { Controls }\end{array}$ & $\begin{array}{l}\text { Controls } \\
\text { Specificity }\end{array}$ & Comment & Ref. \\
\hline 1 & 70 & 100 & 19 & 100 & & 62 \\
\hline 2 & 44 & 84 & 31 & 97 & & 14 \\
\hline 3 & 43 & 95 & 18 & 94 & Community-based study & 63 \\
\hline 4 & 69 & 89 & 17 & 100 & & 64 \\
\hline 5 & 93 & 40 & 41 & 100 & Multicenter study & 56 \\
\hline 6 & 40 & 89 & 36 & 97 & & 65 \\
\hline 7 & 163 & 66 & 65 & 83 & Multicenter study & 66 \\
\hline 8 & 150 & 79 & 100 & 70 & Multicenter study & 67 \\
\hline 9 & 81 & 90 & 15 & 67 & & 41 \\
\hline 10 & 407 & 93 & 93 & 86 & Community-based study & 20 \\
\hline 11 & 60 & 79 & 32 & 82 & & 50 \\
\hline 12 & 54 & 87 & 15 & 93 & & 68 \\
\hline 13 & 47 & 77 & 12 & 92 & & 69 \\
\hline 14 & 41 & 85 & 17 & 95 & & 70 \\
\hline 15 & 80 & 81.3 & 21 & 91 & & 71 \\
\hline 16 & 52 & 79 & 56 & 100 & & 24 \\
\hline 17 & 74 & 95 & 40 & 98 & & 72 \\
\hline 18 & 366 & 59 & 316 & 97 & Multicenter study & 73 \\
\hline 19 & 49 & 88 & 49 & 96 & 3-year follow-up & 74 \\
\hline 20 & 39 & 72 & 12 & 93 & & 75 \\
\hline Total & 2022 & 81.4 & 1005 & 91.5 & & \\
\hline
\end{tabular}

Ref. $=$ reference number.

$\mathrm{A} \beta 42$ in disorders without $\beta$-amyloid plaques, such as $\mathrm{CJD},{ }^{51}$ amyotrophic lateral sclerosis, ${ }^{52}$ and multiple system atrophy. ${ }^{53}$ These findings make a direct correlation questionable between low CSF A $\beta 42$ and deposition of $\mathrm{A} \beta$ in plaque. In contrast, a recent autopsy study found strong correlations between low $\mathrm{A} \beta 42$ in ventricular $\mathrm{CSF}$ and high numbers of plaques in the neocortex and hippocampus, ${ }^{54}$ suggesting that the reduction in CSF $\mathrm{A} \beta 42$ in $\mathrm{AD}$ may at least partly be due to a sequestration of $\beta$-amyloid in plaques.

A $\boldsymbol{\beta 4 0 .}$. There is no change in CSF A $\beta 40$ in $\mathrm{AD} .^{42,55-58}$ As a consequence, a marked decrease in the ratio of $\mathrm{A} \beta 42 / \mathrm{A} \beta 40$ (or increase in the ratio of $\mathrm{A} \beta 40 / \mathrm{A} \beta 42$ ) in CSF has been found in AD in several papers, which is more marked than the reduction in CSF A $\beta 42 .{ }^{56-58} \mathrm{Fu}-$ ture studies are needed to determine if the CSF A $\beta 42 /$ $\mathrm{A} \beta 40$ ratio has a larger diagnostic potential than CSF $\mathrm{A} \beta 42$ alone.

Other A $\boldsymbol{\beta}$ species. Using mass spectrometry, it has been found that there is a heterogeneous set of $\mathrm{A} \beta$ peptides in CSF. ${ }^{59}$ Also using urea-based sodium dodecyl sulfate polyacrylamide gel electrophoresis (SDS-PAGE) and Western immunoblot, ${ }^{47}$ it is possible to separate several C-terminally truncated $\mathrm{A} \beta$ peptides in CSF, including $\mathrm{A} \beta_{1-37}, \mathrm{~A} \beta_{1-38}, \mathrm{~A} \beta_{1-39}, \mathrm{~A} \beta_{1-40}$, and $\mathrm{A} \beta_{1-42}$. $\mathrm{A}$ new finding is that the second most abundant $\mathrm{A} \beta$ peptide is $\mathrm{A} \beta_{1-38}$, which is more abundant than $\mathrm{A} \beta_{1-42} \cdot{ }^{47} \mathrm{In} \mathrm{AD}$, increased CSF levels of both $\mathrm{A} \beta_{1-40}$ and $\mathrm{A} \beta_{1-38}$ were found, along with a decrease in $\mathrm{A} \beta_{1-42}{ }^{47}$ Similar data has been found using surface-enhanced laser desorption/ ionization (SELDI) time-of-flight (TOF) mass spectrometry. ${ }^{48}$ Further studies on large patient and control series are needed to determine the diagnostic potential of these $\mathrm{A} \beta$ variants.

Using two-dimensional electrophoresis combined with Western blotting and mass spectrometry for characterization of formic acid-extracted insoluble $\mathrm{A} \beta$ from brain tissue, ${ }^{60}$ it was found that $\mathrm{N}$-terminally truncated $\mathrm{A} \beta 42$ variants are found in $\mathrm{AD}$ at the earliest stage. Preliminary data from our laboratory show that these N-terminally truncated $\mathrm{A} \beta 42$ species are found in CSF and may be of diagnostic use in early $\mathrm{AD}$ cases.

\section{DIAGNOSTIC PERFORMANCE FOR TAU AND A $\beta$ AS AD BIOMARKERS IN CSF}

The diagnostic performance of T-tau, A $\beta 42$, and P-tau has been extensively studied. In the section below, only studies presenting sensitivity and specificity figures, or in which such figures could be calculated from graphs, are reviewed.

\section{CSF T-tau}

There are numerous studies on the diagnostic performance of CSF T-tau. $^{61}$ The 20 largest studies $^{14,20,24,41,50,56,62-75}$ including more than 2000 AD patients and 1000 controls, evaluating the most commonly used ELISA method for T-tau in CSF, ${ }^{14}$ are summarized in Table 2. The mean sensitivity to discriminate AD from nondemented aged individuals has been $81 \%$, at a specificity level of $91 \%$ (Table 2). 
TABLE 3. Performance of CSF Phospho-Tau as a Biomarker for Alzheimer's Disease

\begin{tabular}{llcccccr}
\hline $\begin{array}{l}\text { Study } \\
\text { Number }\end{array}$ & P-tau Epitope & $\begin{array}{c}\text { Number of } \\
\text { AD Cases }\end{array}$ & $\begin{array}{c}\text { AD } \\
\text { Sensitivity }\end{array}$ & $\begin{array}{c}\text { Number of } \\
\text { Controls }\end{array}$ & $\begin{array}{c}\text { Controls } \\
\text { Specificity }\end{array}$ & Comment & Ref. \\
\hline 1 & P-Thr181 & 80 & 84 & 40 & 88 & & 92 \\
2 & P-Thr181 & 41 & 44 & 17 & 95 & & 70 \\
3 & P-Thr181 & 19 & 58 & 17 & 94 & & 52 \\
4 & P-Thr181 & 108 & 85 & 23 & 91 & Two-center study & 93 \\
5 & P-Thr181 & 51 & 84 & 31 & 84 & & 94 \\
6 & P-Thr181 & 42 & 88 & 43 & 100 & & 26 \\
7 & P-Thr181 & 18 & 89 & 13 & 85 & "Non-AD" controls & 22 \\
8 & P-Ser199 & 36 & 94 & 20 & 80 & Multicenter & 86 \\
9 & P-Ser199 & 236 & 85 & 95 & n.g. & Two-center study & 93 \\
10 & P-Ser199 & 108 & 85 & 23 & 82 & "Non-AD" controls & 71 \\
11 & P-Thr231 & 27 & 85 & 31 & 97 & & 93 \\
12 & P-Thr231 & 82 & 100 & 21 & 91 & Two-center study & 14 \\
13 & P-Thr231 & 108 & 85 & 23 & 96 & & 22 \\
14 & P-Thr181 & 40 & 88 & 31 & 97 & & "Non-AD" controls \\
& P-Thr231 & & & & & \\
15 & P-Thr231 + P-Ser235 & 36 & 53 & 20 & 100 & Cut-off P-tau > 100 pg/mL & 24 \\
16 & P-Ser396+404 & 52 & 94 & 56 & 89 & & \\
Total & & 1084 & 81.3 & 504 & 91.2 & & \\
\hline
\end{tabular}

n.g. = not given

Most of these studies are cross-sectional. There is one large longitudinal study enrolling more than 400 consecutive $\mathrm{AD}$ cases and finding that the sensitivity of CSF T-tau to identify AD was $93 \% .^{20}$ Furthermore, few studies have examined CSF T-tau in pathologically confirmed AD cases. However, in a large study on $131 \mathrm{AD}$ cases in which the diagnosis was confirmed at autopsy in 31 cases, the performance of CSF T-tau and A $\beta 42$ was similar in both groups. ${ }^{43}$

Since CSF T-tau reflects neuronal and axonal degeneration, it is not specific for AD; high CSF T-tau levels will be found in all CNS disorders with neuronal degeneration or damage. The highest levels are found in acute stroke $^{18}$ and in CJD. ${ }^{19}$ Importantly, several studies have consistently found a very marked increase in CSF T-tau in CJD. ${ }^{19,26,51,76-78}$ The mean level of CSF T-tau in CJD is 10-50 times higher than in controls, resulting in a sensitivity close to $100 \%$ and also a specificity above $90 \%$ against other dementias such as $\mathrm{AD} .^{19,26,51,76-78}$ This diagnostic performance is similar to that of CSF 14-3-3 protein. ${ }^{77}$ However, since the method for 14-3-3 protein in CSF is based on SDS-PAGE and Western blot and thus gives results in the form of "14-3-3 positive" or "14-3-3 negative,"79 the quantitative ELISA methods for T-tau may be preferable in the clinical laboratory.

In vascular dementia (VAD), high CSF T-tau has been found in some ${ }^{14,20,50}$ but not in all ${ }^{15,57,69}$ studies. These discrepant findings may depend on the patient characteristics and diagnostic criteria used. High T-tau in clinically diagnosed VAD cases may be caused by concomitant AD pathology in VAD cases, which is a frequent finding at autopsy ${ }^{80,81}$ but difficult to identify clinically.
A study with longitudinal magnetic resonance tomography (MRT) scans in VAD cases ${ }^{20}$ also found that VAD cases with progressive white-matter changes have normal CSF T-tau. Furthermore, in patients with nonacute cerebrovascular disease without dementia, CSF T-tau is normal. ${ }^{82,83}$ One way to interpret these findings is that a high CSF-tau level in a patient with clinical and brain imaging findings indicative of VAD suggests that this patient has mixed (AD/VAD) dementia.

Most studies have found normal to mildly increased CSF T-tau levels in other dementias, such as frontotemporal dementia (FTD) ${ }^{14,15,21,50,52,69,70,73,82-86}$ and Lewy body dementia (LBD). ${ }^{85-90}$

Other than in aged nondemented individuals, normal CSF T-tau is found in depression, alcoholic dementia, and in chronic neurological disorders such as Parkinson's disease (PD) and progressive supranuclear palsy. ${ }^{14,20,50,52,57,63,70,85,88,89,91}$ Thus, CSF T-tau has a clear clinical diagnostic value in the differentiation between $\mathrm{AD}$ and these important and often difficult differential diagnoses.

\section{CSF P-tau}

There are 13 different papers ${ }^{14,22-24,26,52,70,71,86,92-95}$ on the diagnostic performance of the different ELISA methods for P-tau in CSF, including more than $1000 \mathrm{AD}$ patients and 500 controls (Table 3 ). The mean sensitivity to discriminate $\mathrm{AD}$ from nondemented aged individuals has been $81 \%$, at a specificity level of $91 \%$ (Table 3).

In these relatively few papers, there has been a relatively large variation in sensitivity and specificity figures of P-tau between studies using ELISA methods specific 
TABLE 4. Performance of CSF A 342 as a Biomarker for Alzheimer's Disease

\begin{tabular}{|c|c|c|c|c|c|c|}
\hline $\begin{array}{l}\text { Study } \\
\text { Number }\end{array}$ & $\begin{array}{l}\text { Number of } \\
\text { AD Cases }\end{array}$ & $\begin{array}{c}\text { AD } \\
\text { Sensitivity }\end{array}$ & $\begin{array}{c}\text { Number of } \\
\text { Controls }\end{array}$ & $\begin{array}{l}\text { Controls } \\
\text { Specificity }\end{array}$ & Comment & Ref. \\
\hline 1 & 81 & 81 & 51 & 80 & & 41 \\
\hline 2 & 53 & 92 & 21 & 95 & Community-based sample & 49 \\
\hline 3 & 150 & 78 & 100 & 81 & Multicenter study & 67 \\
\hline 4 & 24 & 96 & 19 & 95 & & 89 \\
\hline 5 & 14 & 93 & 20 & 95 & Numbers from graph & 51 \\
\hline 6 & 60 & 93 & 32 & 85 & & 50 \\
\hline 7 & 38 & 76 & 47 & 85 & & 76 \\
\hline 8 & 54 & 89 & 15 & 67 & Numbers from graph & 68 \\
\hline 9 & 27 & 78 & 49 & 100 & & 97 \\
\hline 10 & 9 & 55 & 17 & 94 & & 98 \\
\hline 11 & 20 & 100 & 20 & 95 & & 99 \\
\hline 12 & 74 & 89 & 40 & 95 & & 72 \\
\hline 13 & 19 & 100 & 17 & 94 & & 52 \\
\hline 14 & 49 & 82 & 49 & 80 & 3-year follow-up & 74 \\
\hline 15 & 51 & 78 & 31 & 90 & & 94 \\
\hline 16 & 18 & 89 & 13 & 85 & Moderate decrease; median & 95 \\
\hline Total & 660 & 85.9 & 541 & 88.5 & & \\
\hline
\end{tabular}

for different phosphorylated tau epitopes (Table 3). Therefore, a study was performed to directly compare the diagnostic performance of P-Tau ${ }_{181}$, P-Tau ${ }_{199}$, and P$\mathrm{Tau}_{231}$ in the same patient material. ${ }^{93}$ Among cases with $\mathrm{AD}$, DLB, FTD, VAD, and a group with other neurological disorders, all three P-tau assays performed equally well in the discrimination of $\mathrm{AD}$ from other disorders and nondemented controls..$^{93}$ Minor differences found between the assays were that group separation was maximized between $\mathrm{AD}$ and FTD using $\mathrm{P}-\mathrm{Tau}_{231}$ and between AD and DLB using P-Tau ${ }_{181} \cdot{ }^{93}$ Thus, the sensitivity for $\mathrm{AD}$ seems equal, whereas minor differences in the phosphorylation of specific tau epitopes between dementia disorders may be reflected in the CSF level of the corresponding P-tau variant.

Interestingly, the specificity of CSF P-tau to differentiate $\mathrm{AD}$ from other dementias seems to be higher than for T-tau and A $\beta 42$. Normal CSF levels of P-tau are found in psychiatric disorders such as depression, ${ }^{14,96}$ in chronic neurological disorders such as amyotrophic lateral sclerosis and $\mathrm{PD},{ }^{14,52,70}$ and also in other most cases with other dementia disorders such as VAD, FTD, and LBD. ${ }^{21,52,70,71,86,92,93}$ Furthermore, although there is a very marked increase in CSF T-tau in CJD, most patients with CJD have normal or only mildly elevated CSF P-tau. ${ }^{26}$ In a large set of patients with CJD cases and other dementias, the ratio of P-tau to T-tau in CSF was found to discriminate CJD from other neurodegenerative disorders without any overlap. ${ }^{26}$

\footnotetext{
A $\beta 42$

There are 16 studies ${ }^{41,49-52,67,68,72,74,76,89,94,95,97-99}$ on the diagnostic performance of the most commonly used ELISA method ${ }^{41}$ for $\mathrm{A} \beta 42$ in CSF (Table 4). These
}

studies include more than $650 \mathrm{AD}$ patients and 500 controls (Table 4). The mean sensitivity to discriminate between $\mathrm{AD}$ and normal aging is $86 \%$, at a specificity level of $89 \%$ (Table 4 ).

Other than in nondemented aged individuals, normal CSF $A \beta 42$ is found in psychiatric disorders such as depression, and in chronic neurological disorders such as $\mathrm{PD}$, and progressive supranuclear palsy. ${ }^{50,52,53,89}$ Thus, CSF $A \beta 42$ helps in the clinical differentiation between $\mathrm{AD}$ and these important and often difficult differential diagnoses.

However, data on the performance of CSF A $\beta 42$ in the discrimination between $\mathrm{AD}$ and other dementias and neurological disorders are relatively limited. A mild to moderate decrease in CSF A $\beta 42$ is found in a percentage of patients with FTD and VAD. ${ }^{50,52,67,72}$

\section{Combination of CSF biomarkers for AD}

There are several studies in which the diagnostic potential of the combination of CSF T-tau and A $\beta 42$ have been evaluated. For the most commonly used ELISA methods for $\mathrm{T}-\mathrm{tau}^{14}$ and $\mathrm{A} \beta 42,{ }^{41}$ sensitivity and specificity figures are available from 12 studies (Table 5). ${ }^{41,43,50,52,67,72,74,97,99-102}$ The sensitivity and specificity for the combination of CSF T-tau and Ab42 have been slightly higher $(89 \%$ and $90 \%$, respectively) than for T-tau (81\% and $91 \%$, respectively) or Ab42 (86\% and $89 \%$, respectively) alone (Tables 2,4 , and 5).

Other combinations of CSF markers have also resulted in slightly better diagnostic performance than the use of single markers. In a study on the combination of CSF $\mathrm{P}-\mathrm{Tau}_{181}$ and $\mathrm{A} \beta 42$, the sensitivity was $86 \%$ at a specificity of $97 \%,{ }^{94}$ and in another study the combination of 
TABLE 5. Performance of the Combination of CSF Total Tau and A $\beta 42$ as Biomarkers for Alzheimer's Disease

\begin{tabular}{|c|c|c|c|c|c|c|c|}
\hline $\begin{array}{l}\text { Study } \\
\text { Number }\end{array}$ & $\begin{array}{l}\text { Number of } \\
\text { AD Cases }\end{array}$ & $\begin{array}{c}\text { AD } \\
\text { Sensitivity }\end{array}$ & $\begin{array}{c}\text { Number of } \\
\text { Controls }\end{array}$ & $\begin{array}{c}\text { Controls } \\
\text { Specificity }\end{array}$ & $\begin{array}{l}\text { Method for } \\
\text { Discrimination }\end{array}$ & Comment & Ref. \\
\hline 1 & 105 & 94 & n.a. & n.a. & Discrimination line & Community-based patient sample & 101 \\
\hline 2 & 16 & 88 & 15 & 80 & Discrimination line & & 100 \\
\hline 3 & 35 & 92 & 19 & 90 & PCA & & 102 \\
\hline 4 & 131 & 92 & 72 & 82 & Quadrant with cut-offs & Includes 31 autopsy-proven AD & 43 \\
\hline 5 & 150 & 85 & 100 & 87 & Discrimination line & Multicenter study & 67 \\
\hline 6 & 60 & 73 & 32 & 84 & Quadrant with cut-offs & & 50 \\
\hline 7 & 27 & 85 & 49 & 100 & Discrimination line & & 97 \\
\hline 8 & 19 & 100 & 17 & 100 & Quadrant with cut-offs & & 52 \\
\hline 9 & 49 & 96 & 49 & 86 & $\mathrm{~T}$-tau/A $\beta 42$ ratio & 3-year follow-up & 74 \\
\hline 10 & 74 & 92 & 40 & 95 & Discrimination line & & 72 \\
\hline 11 & 81 & 74 & 15 & 93 & Quadrant with cut-offs & & 41 \\
\hline 12 & 20 & 100 & 20 & 95 & Quadrant with cut-offs & & 99 \\
\hline Total & 767 & 89.3 & 428 & 90.2 & & & \\
\hline
\end{tabular}

PCA $=$ principal component analysis; n.a. $=$ not applicable .

CSF T-tau and P-tau $396 / 404$ resulted in a sensitivity of $96 \%$ at a specificity of $100 \% .^{24}$

\section{CSF MARKERS IN EARLY AD AND MCI}

\section{Early AD}

The performance of CSF T-tau, P-tau, and A $\beta 42$ in early $\mathrm{AD}$ cases with Mini-Mental State Examination (MMSE) scores above 23-25 has been examined in some studies. Also in this early phase of the disease, the sensitivity figures have been similar to those found in more advanced AD cases. ${ }^{20,49,65,67,103-105}$

\section{MCI}

Several studies have also evaluated the performance of CSF markers in MCI cases that developed AD during a clinical follow-up period of 1-2 years, finding sensitivity figures similar to those found in $\mathrm{AD}$ cases with clinical dementia. ${ }^{68,100,101,106-110}$

Some studies have evaluated the performance of CSF biomarkers to identify MCI cases that later will progress to $\mathrm{AD}$ with dementia, i.e., have "preclinical" or incipient AD. In the first study using this approach, high CSF T-tau was found to discriminate MCI patients that later progressed to $\mathrm{AD}$ from those that did not progress, with $90 \%$ sensitivity and $100 \%$ specificity. ${ }^{111}$ Another study found high CSF T-tau and low CSF A $\beta 42$ in 90\% of MCI cases that later progressed to $\mathrm{AD}$ with dementia, as compared with $10 \%$ of stable MCI cases. ${ }^{109}$ Similarly, a marked increase in CSF P-tau was found in MCI cases that at follow-up had progressed to $\mathrm{AD}$ compared with stable MCI cases. ${ }^{112}$ A recent population-based study also found that reduced CSF A $\beta 42$ is present in asymptomatic elderly who developed dementia during a 3-year follow-up period. ${ }^{113}$

The fact that only $\sim 15 \%$ of $\mathrm{MCI}$ cases progress to $\mathrm{AD}$ each year ${ }^{6}$ makes a very extensive follow-up period (more than 5 years) needed to ascertain which $\mathrm{MCI}$ patients will not develop dementia, i.e., have stable MCI. This may introduce a risk that the specificity figures in these studies thus far are too low. However, although further longitudinal studies clearly are needed, data from the studies on early $\mathrm{AD}$ and MCI suggest that these CSF markers may be of clinical value to differentiate $\mathrm{MCI}$ cases that will progress to $\mathrm{AD}$ from benign $\mathrm{MCI}$ cases.

\section{Use of AD Biomarkers in CSF in Clinical Practice}

The diagnostic performance of $\mathrm{AD}$ biomarkers has been evaluated in clinical practice in two studies. ${ }^{20,101} \mathrm{In}$ these studies, the CSF markers have been evaluated on prospective patient samples from clinical practice, and ELISA assays have been run each week in clinical neurochemical routine. The diagnostic performance of CSF $\mathrm{T}$-tau ${ }^{20}$ and the combination of CSF T-tau and A $\beta 42^{101}$ has been similar to that found in other studies, with a high ability to differentiate AD from normal aging, depression, and $\mathrm{PD}$, but lower specificity against other dementias like VAD and LBD.

A summary of the diagnostic performance of T-tau, P-tau, and $\mathrm{A} \beta 42$ is given in Table 6. Details on the performance of these CSF markers in the separation between $\mathrm{AD}$ and nondemented aged individuals has been published previously. ${ }^{61}$ The diagnostic performance of the CSF markers seems to be highest in the differentiation between $\mathrm{AD}$ and several important differential diagnoses, including normal aging, depression, alcohol dementia, and PD (Table 6). Another useful clinical application is the identification of CJD in cases with rapidly progressive dementia, in which the combination of very marked increased CSF T-tau and normal or mildly increased P-tau has high diagnostic value. Lastly, these CSF markers may be useful in identifying mixed $\mathrm{AD} / \mathrm{VAD}$ dementia. 
TABLE 6. Summary of the Specificity of CSF Markers for Alzheimer's Disease

\begin{tabular}{|c|c|c|c|}
\hline Disorder & Total Tau & Phospho-Tau & $\mathrm{A} \beta 42$ \\
\hline Alzheimer's disease & Moderate to marked increase & $\begin{array}{l}\text { Moderate to marked } \\
\text { increase }\end{array}$ & Moderate to marked decrease \\
\hline Normal aging & Normal & Normal & Normal \\
\hline Depression & Normal & Normal & Normal \\
\hline Alcohol dementia & Normal & Normal & Normal \\
\hline Parkinson's disease & Normal & Normal & Normal \\
\hline Creutzfeldt-Jakob disease & Very marked increase & $\begin{array}{l}\text { Normal, but some cases } \\
\text { with mild increase }\end{array}$ & Normal to marked decrease \\
\hline Frontotemporal dementia & Normal to mild increase & Normal & Mild to moderate decrease \\
\hline Lewy body dementia & Normal to mild increase & Normal to mild increase & Moderate decrease \\
\hline Vascular dementia & $\begin{array}{l}\text { Inconsistent data, some studies } \\
\text { with normal and some with } \\
\text { increased levels }\end{array}$ & Normal & Mild to moderate decrease \\
\hline Acute stroke & $\begin{array}{l}\text { Mild to very marked increase, } \\
\text { depending on the infarct size }\end{array}$ & Normal & Normal \\
\hline $\begin{array}{l}\text { Non-acute CVD without } \\
\text { dementia }\end{array}$ & Normal & N.E. & Normal \\
\hline
\end{tabular}

CVD = cerebrovascular disease; N.E. = not examined.

The lower specificity against other dementias, such as LBD and FTD, may hamper the clinical utility of these CSF markers. However, in the clinic, dementias with differing history, symptoms, and findings on brain imaging (e.g., FTD, VAD) can often be identified by means of the medical history, clinical examination, and auxiliary investigations (e.g., blood tests, SPECT, and computerized tomography or MRT). A common "final question" is whether a patient with $\mathrm{MCI}$ will progress to $\mathrm{AD}$ with dementia or not. Although more studies are needed, these CSF markers seem to be of clinical use in the identification of incipient AD in MCI cases. Early diagnosis of $\mathrm{AD}$ is not only of importance to be able to initiate symptomatic treatment with $\mathrm{AChE}$ inhibitors, but will be the basis for initiation of treatment with drugs aimed at slowing down or arresting the degenerative process, such as $\gamma$-secretase inhibitors, if these prove to affect $A D$ pathology and to have a clinical effect.

\section{Candidate CSF Protein Biomarkers for AD}

In the following section, some promising candidate CSF protein biomarkers that have been evaluated in a few studies, often by single research groups, are reviewed.

\section{Ubiquitin}

Ubiquitin is a small $(8.7 \mathrm{kDa})$ protein involved in the ATP-dependent degradation of proteins, in which it is covalently conjugated to lysine residues of target proteins, for which it serves as a signal for degradation of the protein by proteases. ${ }^{114-116}$ Ubiquitin-conjugated proteins may also be stable and exist in the cell indefinitely. ${ }^{116}$ In AD brain, the paired helical filaments (PHF) in tangles are ubiquitinated. ${ }^{117,118}$ The level of ubiquitin in $\mathrm{AD}$ cerebral cortex is increased several-fold and correlates with the amount of neurofibrillary changes. ${ }^{119}$

Using an ELISA method based on the monoclonal antibody 5-25, raised against PHF from AD brains, ${ }^{120}$ Mehta and co-workers reported in 1985 high levels of "paired helical filaments antigen" in CSF in AD. ${ }^{121}$ This antibody is specific for residues 64-76 of ubiquitin ${ }^{122}$ and recognizes this epitope on ubiquitin-conjugated proteins, including PHF in tangles. ${ }^{117}$ This finding has been replicated in subsequent studies. ${ }^{123}$ There is also a correlation between ubiquitin in CSF and in brain tissue. ${ }^{124}$ Using an ELISA method based on the monoclonal antibody 1510 , which is specific for free nonconjugated ubiquitin, an increase in CSF-ubiquitin was found in AD. ${ }^{125}$

Thus, there seems to be an increase in both free ubiquitin and of ubiquitin-conjugated proteins in CSF in AD. Further studies are on the way on the diagnostic potential of ubiquitin in CSF as a protein biomarker for $\mathrm{AD}$.

\section{NF proteins}

NF proteins are structural components in the neuronal axons that are important for axonal structure and transport. Neurofilaments are composed of three subunits based on the molecular weight, termed high (NF-H), medium (NF-M), and light (NF-L).

The light subunit of the NF protein (NF-L) is mainly localized in the large myelinated axons. ${ }^{126}$ The CSF level of NF-L correlates with the degree of white matter changes in the brain. ${ }^{127}$ CSF-NFL is therefore suggested to be a biomarker for degeneration of large myelinated axons. Although increased CSF NF-L levels are found in $\mathrm{AD},{ }^{102,127-129}$ CSF NF-L is even more increased in FTD and in VAD. ${ }^{127-129}$ Also using another ELISA method, a 
more pronounced increase in CSF NF-L was found in VAD than in $\mathrm{AD} .{ }^{130}$ These findings suggest that CSF NF-L may be valuable in the differentiation between $A D$ and VAD/FTD.

NF proteins are phosphorylated, which regulates their function in axonal transport and their tendency for polymerization. ${ }^{131}$ Using ELISA methods based on antibodies reacting with phosphorylated NF, a marked increase in phospho-NF-H/M was found in $\mathrm{AD}$ compared with VAD and other neurological disorders. ${ }^{130}$ These promising findings call for further studies on the diagnostic potential of different forms of NF proteins in CSF.

\section{GAP43 (neuromodulin)}

GAP43, or neuromodulin, is a protein localized in the presynaptic terminals and axons of cortical neurons. ${ }^{132-134}$ In AD brain, GAP43 is found in the dystrophic neurites in plaques. ${ }^{135,136}$ GAP43 protein levels are decreased in the frontal cortex and the hippocampus in $\mathrm{AD} .^{137-139}$

GAP43 is secreted to the CSF at which it serves as a potential marker for synaptic degeneration or plasticity. ${ }^{139}$ In AD, increased CSF levels of GAP43 are found, although CSF GAP43 is normal in FTD and in PD. ${ }^{50,69,140}$ There is a clear correlation between the CSF levels of T-tau and $\mathrm{GAP}^{50,69}$ and some data suggest that the ratio of CSF GAP43/T-tau may be of diagnostic importance.$^{50}$ However, further studies are needed on the potential of GAP43 as a diagnostic marker for AD.

\section{NTP and AD7c protein}

NTP was identified a brain protein cross-reacting with antibodies against pancreatic thread protein (PTP). ${ }^{141}$ Both brain NTP immunoreactivity ${ }^{141,142}$ and mRNA levels ${ }^{143}$ are increased in AD.

In the first study on NTP in CSF, a marked increase was found in $\mathrm{AD} .{ }^{144}$ Based on the knowledge that the antibodies used by de la Monte and co-workers ${ }^{144}$ were generated against human $\mathrm{PTP}^{145}$ and that the concentration of PTP is about one million times higher in pancreatic fluid than that of NTP in CSF, ${ }^{145}$ a study was performed to examine the origin of NTP in CSF. ${ }^{146}$ The level of NTP was about 40 times higher in serum than in CSF and highly significant correlations were found between serum-NTP and CSF-NTP and between the CSF/ serum albumin ratio (as a marker for the blood-brain barrier function) and CSF-NTP. ${ }^{146}$ These findings suggested that NTP in CSF comes from the serum by passage over the blood-brain barrier. Indeed, increased CSFNTP was only found in AD and VAD cases with signs of blood-brain barrier damage. ${ }^{146}$

These disappointing findings initiated a search for a brain-specific NTP transcript. Screening a human brain cDNA library, again with the same antibodies against PTP, ${ }^{144,145}$ a cDNA named AD7c was isolated. ${ }^{147}$ Despite the nucleotide sequence showing no homology to PTP, this cDNA was named AD7c-NTP. ${ }^{147}$
Using a new ELISA method based on antibodies generated against recombinant AD7c-NTP protein, a marked increase in CSF-AD7c-NTP was found in AD compared with controls and other neurological disorders including PD and multiple sclerosis. ${ }^{147}$ Although initial studies reported a good separation between $\mathrm{AD}$ and control groups, ${ }^{147,148}$ later studies showed a less pronounced increase, with a marked overlap between $\mathrm{AD}$ and both controls and patients with PD. ${ }^{88}$ Furthermore, an evidence-based evaluation of this biomarker is rendered because, to my knowledge, the AD7c-NTP ELISA method is not commercially available; CSF samples have to be sent for analyses to the company that developed the method. Scientific studies performed independently by the research community are thus still lacking.

\section{REFERENCES}

1. Blennow K, Skoog I. Genetic testing for Alzheimer's disease: how close is reality? Curr Opin Psychiatry 12:487-493, 1999.

2. Tomlinson BE, Blessed G, Roth M. Observations on the brains of demented old people. J Neurol Sci 11:205-242, 1970.

3. Davies L, Wolska B, Hilbich C, Multhaup G, Martins R, Simms $\mathrm{G}$ et al. A4 amyloid protein deposition and the diagnosis of Alzheimer's disease: prevalence in aged brains determined by immunocytochemistry compared with conventional neuropathologic techniques. Neurology 38:1688-1693, 1988.

4. McKhann G, Drachman D, Folstein M, Katzman R, Price D, Stadlan EM. Clinical diagnosis of Alzheimer's disease: report of the NINCDS-ADRDA Work Group under the auspices of department of health and human services task force on Alzheimer's disease. Neurology 34:939-944, 1984.

5. Petersen RC, Smith GE, Waring SC, Ivnik RJ, Tangalos EG, Kokmen E. Mild cognitive impairment: clinical characterization and outcome. Arch Neurol 56:303-308, 1999.

6. DeCarli C. Mild cognitive impairment: prevalence, prognosis, aetiology, and treatment. Lancet Neurol 2:15-21, 2003.

7. Blennow K, Wallin A. Clinical heterogeneity of probable Alzheimer's disease. J Geriatr Psychiatry Neurol 5:106-113, 1992.

8. Goedert M, Spillantini MG, Potier MC, Ulrich J, Crowther RA. Cloning and sequencing of the cDNA encoding an isoform of microtubule-associated protein tau containing four tandem repeats: differential expression of tau protein mRNAs in human brain. EMBO J 8:393-399, 1989.

9. Buée L, Bussiere T, Buee-Scherrer V, Delacourte A, Hof PR. Tau protein isoforms, phosphorylation and role in neurodegenerative disorders. Brain Res Brain Res Rev 33:95-130, 2000.

10. Iqbal K, Alonso Adel C, El-Akkad E, Gong CX, Haque $\mathrm{N}$ et al. Pharmacological targets to inhibit Alzheimer neurofibrillary degeneration. J Neural Transm Suppl 62:309-319, 2002.

11. Grundke-Iqbal I, Iqbal K, Tung YC, Quinlan M, Wisniewski HM, Binder LI. Abnormal phosphorylation of the microtubule-associated protein $\tau$ (tau) in Alzheimer cytoskeletal pathology. Proc Natl Acad Sci USA 83:4913-4917, 1986.

12. Iqbal K, Alonso AD, Gondal JA, Gong CX, Haque N, Khatoon S et al. Mechanism of neurofibrillary degeneration and pharmacologic therapeutic approach. J Neural Transm Suppl 59:213-222, 2000.

13. Vandermeeren M, Mercken M, Vanmechelen E, Six J, van de Voorde A, Martin JJ et al. Detection of $\tau$ proteins in normal and Alzheimer's disease cerebrospinal fluid with a sensitive sandwich enzyme-linked immunosorbent assay. J Neurochem 61:1828-1834, 1993.

14. Blennow K, Wallin A, Ågren H, Spenger C, Siegfried J, Vanmechelen E. Tau protein in cerebrospinal fluid: a biochemical diagnostic marker for axonal degeneration in Alzheimer's disease? Mol Chem Neuropathol 26:231-245, 1995. 
15. Vigo-Pelfrey C, Seubert P, Barbour R, Blomquist C, Lee M, Lee $\mathrm{D}$ et al. Elevation of microtubule-associated protein tau in the cerebrospinal fluid of patients with Alzheimer's disease. Neurology 45:788-793, 1995.

16. Mori H, Hosoda K, Matsubara E, Nakamoto T, Furiya Y, Endoh $\mathrm{R}$ et al. Tau in cerebrospinal fluids: establishment of the sandwich ELISA with antibody specific to the repeat sequence in tau. Neurosci Lett 186:181-183, 1995.

17. Blennow K, Vanmechelen E, Hampel H. CSF total tau, Ab42 and phosphorylated tau protein as biomarkers for Alzheimer's disease. Mol Neurobiol 24:87-97, 2001.

18. Hesse C, Rosengren L, Vanmechelen E, Vanderstichele H, Jensen C, Davidsson P et al. Cerebrospinal fluid markers for Alzheimer's disease evaluated after acute ischemic stroke. J Alzheimers Dis 2:199-206, 2000.

19. Otto M, Wiltfang J, Tumani H, Zerr I, Lantsch M, Kornhuber J et al. Elevated levels of tau-protein in cerebrospinal fluid of patients with Creutzfeldt-Jakob disease. Neurosci Lett 225:210-212, 1997.

20. Andreasen N, Minthon L, Clarberg A, Davidsson P, Gottfries J, Vanmechelen E et al. Sensitivity, specificity and stability of CSF t-tau in $\mathrm{AD}$ in a community-based patient sample. Neurology 53:1488-1494, 1999.

21. Vanmechelen E, Vanderstichele H, Davidsson P, Van Kerschaver E, Van Der Perre B, Sjogren M et al. Quantification of tau phosphorylated at threonine 181 in human cerebrospinal fluid: a sandwich ELISA with a synthetic phosphopeptide for standardization. Neurosci Lett 285:49-52, 2000.

22. Ishiguro K, Ohno H, Arai H, Yamaguchi H, Urakami K, Park JM et al. Phosphorylated tau in human cerebrospinal fluid is a diagnostic marker for Alzheimer's disease. Neurosci Lett 270:91-94, 1999.

23. Kohnken R, Buerger K, Zinkowski R, Miller C, Kerkman D, DeBernardis J et al. Detection of tau phosphorylated at threonine 231 in cerebrospinal fluid of Alzheimer's disease patients. Neurosci Lett 287:187-190, 2000.

24. Hu YY, He SS, Wang X, Duan QH, Grundke-Iqbal I, Iqbal K et al. Levels of nonphosphorylated and phosphorylated tau in cerebrospinal fluid of Alzheimer's disease patients: an ultrasensitive bienzyme-substrate-recycle enzyme-linked immunosorbent assay. Am J Pathol 160:1269-1278, 2002.

25. Hesse C, Rosengren L, Andreasen N, Davidsson P, Vanderstichele $\mathrm{H}$, Vanmechelen $\mathrm{E}$ et al. Transient increase in CSF total tau but not phospho-tau after acute stroke. Neurosci Lett 297: 187-190, 2001.

26. Riemenschneider M, Wagenpfeil S, Vanderstichele H, Otto M, Wiltfang J, Kretzschmar H et al. Phospho-tau/total tau ratio in cerebrospinal fluid discriminates Creutzfeldt-Jakob disease from other dementias. Mol Psychiatry 8:343-347, 2003.

27. Masters CL, Simms G, Weinman NA, Multhaup G, McDonald BL, Beyreuther K. Amyloid plaque core protein in Alzheimer's disease and Down syndrome. Proc Natl Acad Sci USA 82:42454249, 1985.

28. Haas C, Selkoe DJ. Cellular processing of $\beta$-amyloid precursor protein and the genesis of amyloid $\beta$-peptide. Cell 75:10391042, 1993.

29. Kang J, Lemaire HG, Unterbeck A, Salbaum JM, Masters CL, Grzeschik KH et al. The precursor of Alzheimer's disease amyloid A4 protein resembles a cell-surface receptor. Nature 325: 733-736, 1987.

30. Seubert P, Vigo-Pelfrey C, Esch F, Lee M, Dovey H, Davis D et al. Isolation and quantification of soluble Alzheimer's $\beta$-peptide from biological fluids. Nature 359:325-327, 1992.

31. Van Nostrand WE, Wagner SL, Shankle WR, Farrow JS, Dick M, Rozemuller JM et al. Decreased levels of soluble amyloid $\beta$-protein precursor in cerebrospinal fluid of live Alzheimer disease patients. Proc Natl Acad Sci USA 89:2551-2555, 1992.

32. Farlow M, Ghetti B, Benson MD, Farrow JS, van Nostrand WE, Wagner SL. Low cerebrospinal-fluid concentrations of soluble amyloid $\beta$-protein precursor in hereditary Alzheimer's disease. Lancet 340:453-454, 1992.

33. Tabaton M, Nunzi MG, Xue R, Usiak M, Autilio-Gambetti L, Gambetti P. Soluble amyloid $\beta$-protein is a marker of Alzheimer amyloid in brain but not in cerebrospinal fluid. Biochem Biophys Res Commun 200:1598-1603, 1994.

34. van Gool WA, Kuiper MA, Walstra GJ, Wolters EC, Bolhuis PA. Concentrations of amyloid $\beta$-protein in cerebrospinal fluid of patients with Alzheimer's disease. Ann Neurol 37:277-279, 1995.

35. Motter, R, Vigo-Pelfrey, C, Kholodenko D, Barbour R, JohnsonWood K, Galasko D et al. Reduction of $\beta$-amyloid peptide42 in the cerebrospinal fluid of patients with Alzheimer's disease. Ann Neurol 38:643-648, 1995.

36. Southwick PC, Yamagata SK, Echols CL, Higson GJ, Neynaber $\mathrm{SA}$, Parson RE et al. Assessment of amyloid $\beta$-protein in cerebrospinal fluid as an aid in the diagnosis of Alzheimer's disease. $J$ Neurochem 66:259-265, 1996.

37. Jarrett JT, Berger EP, Lansbury PT. The carboxy terminus of the $\beta$-amyloid protein is critical for the seeding of amyloid formation: implications for the pathogenesis of Alzheimer's disease. Biochemistry 32:4693-4697, 1993.

38. Iwatsubo T, Odaka A, Suzuki N, Mizusawa H, Nukina N, Ihara Y. Visualization of $A \beta 42(43)$ and $A \beta 40$ in senile plaques with end-specific $\mathrm{A} \beta$ monoclonals: evidence that an initially deposited species is A $\beta 42(43)$. Neuron 13:45-53, 1994.

39. Tamaoka A, Kondo T, Odaka A, Sahara N, Sawamura N, Ozawa $\mathrm{K}$ et al. Biochemical evidence for the long-tail form (A $\beta$ 1-42/43) of amyloid $\beta$ protein as a seed molecule cerebral deposits of Alzheimer's disease. Biochem Biophys Res Commun 205:834842, 1994.

40. Miller DL, Papayannopoulos IA, Styles J, Bobin SA, Lin YY, Biemann K, Iqbal K. Peptide composition of the cerebrovascular and senile plaque core amyloid deposits of Alzheimer's disease. Arch Biochem Biophys 301:41-52, 1993.

41. Vanderstichele H, Blennow K, D'Heuvaert ND, Buyse MA, Wallin $\mathrm{A}$, Andreasen $\mathrm{N}$ et al. Development of a specific diagnostic test for measurement of $\beta$-amyloid $(1-42)$ in CSF. In: Progress in Alzheimer's and Parkinson's diseases (Fisher A, Hanin I, Yoshida M, eds), pp 773-778. New York: Plenum, 1998.

42. Mehta PD, Pirttila T, Mehta SP, Sersen EA, Aisen PS, Wisniewski HM. Plasma and cerebrospinal fluid levels of amyloid $\beta$ proteins 1-40 and 1-42 in Alzheimer disease. Arch Neurol $57: 100-105,2000$.

43. Sunderland T, Linker G, Mirza N, Putnam KT, Friedman DL, Kimmel LH et al. Decreased $\beta$-amyloid1-42 and increased tau levels in cerebrospinal fluid of patients with Alzheimer disease. JAMA 289:2094-2103, 2003.

44. Ida N, Hartmann T, Pantel J, Schroder J, Zerfass R, Forstl H et al. Analysis of heterogeneous A4 peptides in human cerebrospinal fluid and blood by a newly developed sensitive Western blot assay. J Biol Chem 271:22908-22914, 1996.

45. Schroder J, Pantel J, Ida N, Essig M, Hartmann T, Knopp MV et al. Cerebral changes and cerebrospinal fluid $\beta$-amyloid in Alzheimer's disease: a study with quantitative magnetic resonance imaging. Mol Psychiatry 2:505-507, 1997.

46. Jensen M, Schroder J, Blomberg M, Engvall B, Pantel J, Ida N et al. Cerebrospinal fluid A $\beta 42$ is increased early in sporadic Alzheimer's disease and declines with disease progression. $\mathrm{Ann} \mathrm{Neu-}$ rol 45:504-511, 1999.

47. Wiltfang J, Esselmann H, Bibl M, Smirnov A, Otto M, Paul S et al. Highly conserved and disease-specific patterns of carboxyterminally truncated $\mathrm{A} \beta$ peptides $1-37 / 38 / 39$ in addition to $1-40 / 42$ in Alzheimer's disease and in patients with chronic neuroinflammation. J Neurochem 81:481-496, 2002.

48. Lewczuk P, Esselmann H, Meyer M, Wollscheid V, Neumann M, Otto $\mathrm{M}$ et al. The amyloid- $\beta(\mathrm{A} \beta)$ peptide pattern in cerebrospinal fluid in Alzheimer's disease: evidence of a novel carboxyterminally elongated A $\beta$ peptide. Rapid Commun Mass Spectrom 17: 1291-1296, 2003.

49. Andreasen N, Hesse C, Davidsson P, Wallin A, Minthon L, Winblad B et al. Cerebrospinal fluid $\beta$-amyloid ${ }_{(1-42)}$ in Alzheimer's disease: differences between early- and late-onset Alzheimer disease and stability during the course of disease. Arch Neurol 56:673-680, 1999.

50. Sjögren M, Minthon L, Davidsson P, Granérus AK, Clarberg A, Vanderstichele $\mathrm{H}$ et al. CSF levels of tau, $\beta$-amyloid1-42 and 
GAP-43 in frontotemporal dementia, other types of dementia and normal aging. J Neural Transm 107:563-579, 2000.

51. Otto M, Esselmann H, Schulz-Shaeffer W, Neumann M, Schroter A, Ratzka P et al. Decreased $\beta$-amyloid1-42 in cerebrospinal fluid of patients with Creutzfeldt-Jakob disease. Neurology 54:1099_ $1102,2000$.

52. Sjögren M, Davidsson $\mathrm{P}$, Wallin A, Granerus AK, Grundström E, Askmark $\mathrm{H}$ et al. Decreased CSF $\beta$-amyloid42 in Alzheimer's disease and amyotrophic lateral sclerosis may reflect mismetabolism of $\beta$-amyloid induced by separate mechanisms. Dement Geriatr Cogn Disord 13:112-118, 2002.

53. Holmberg B, Johnels B, Blennow K, Rosengren L. Cerebrospinal fluid $A \beta 42$ is reduced in multiple system atrophy but normal in Parkinson's disease and progressive supranuclear palsy. Mov Disord 18:186-190, 2003.

54. Strozyk D, Blennow K, White LR, Launer LJ. CSF A $\beta 42$ levels correlate with amyloid-neuropathology in a population-based autopsy study. Neurology 60:652-656, 2003.

55. Tamaoka A, Sawamura N, Fukushima T, Shoji S, Matsubara E, Shoji M et al. Amyloid $\beta$ protein 42(43) in cerebrospinal fluid of patients with Alzheimer's disease. J Neurol Sci 148:41-45, 1997.

56. Kanai M, Matsubara E, Isoe K, Urakami K, Nakashima K, Arai $\mathrm{H}$ et al. Longitudinal study of cerebrospinal fluid levels of tau, A $\beta 1-40$, and A $\beta 1-42(43)$ in Alzheimer's disease: a study in Japan. Ann Neurol 44:17-26, 1998.

57. Shoji M, Matsubara E, Kanai M, Watanabe M, Nakamura T, Tomidokoro $\mathrm{Y}$ et al. Combination assay of CSF tau, A $\beta$ 1-40 and $\mathrm{A} \beta$ 1-42(43) as a biochemical marker of Alzheimer's disease. J Neurol Sci 158:134-140, 1998.

58. Fukuyama R, Mizuno T, Mori S, Nakajima K, Fushiki S, Yanagisawa K. Age-dependent change in the levels of $A \beta 40$ and $A \beta 42$ in cerebrospinal fluid from control subjects, and a decrease in the ratio of $A \beta 42$ to $A \beta 40$ level in cerebrospinal fluid from Alzheimer's disease patients. Eur Neurol 43:155-160, 2000.

59. Vigo-Pelfrey C, Lee D, Keim P, Lieberburg I, Schenk DB. Characterization of $\beta$-amyloid peptide from human cerebrospinal fluid. J Neurochem 61:1965-1968, 1993.

60. Sergeant N, Bombois S, Ghestem A, Drobecq H, Kostanjevecki $\mathrm{V}$, Missiaen $\mathrm{C}$ et al. Truncated $\beta$-amyloid peptide species in pre-clinical Alzheimer's disease as new targets for the vaccination approach. J Neurochem 85:1581-1591, 2003.

61. Blennow K, Hampel H. CSF markers for incipient Alzheimer's disease. Lancet Neurol 2:605-613, 2003.

62. Arai H, Terajima M, Miura M, Higuchi S, Muramatsu T, Machida $\mathrm{N}$ et al. Tau in cerebrospinal fluid: a potential diagnostic marker in Alzheimer's disease. Ann Neurol 38:649-652, 1995.

63. Andreasen N, Vanmechelen E, Van de Voorde A, Davidsson P, Hesse C, Tarvonen S, Räihä I, Sourander L, Winblad B, Blennow $\mathrm{K}$. Cerebrospinal fluid tau protein as a biochemical marker for Alzheimer's disease: a community-based follow-up study. J Neurol Neurosurg Psychiatry 64:298-305, 1998.

64. Arai H, Satoh-Nakagawa T, Higuchi M, Morikawa Y, Miura M, Kawakami H, Seki H, Takase S, Sasaki H. No increase in cerebrospinal fluid tau protein levels in patients with vascular dementia. Neurosci Lett 256:174-176, 1998.

65. Kurz A, Riemenschneider M, Buch K, Willoch F, Bartenstein P, Muller $U$ et al. Tau protein in cerebrospinal fluid is significantly increased at the earliest stage of Alzheimer disease. Alzheimer Dis Assoc Disord 12:372-377, 1998.

66. Nishimura T, Takeda M, Nakamura Y, Yosbida Y, Arai H, Sasaki $\mathrm{H}$ et al. Basic and clinical studies on the measurement of tau protein in cerebrospinal fluid as a biological marker for Alzheimer's disease and related disorders: multicenter study in Japan. Methods Find Exp Clin Pharmacol 20:227-235, 1998.

67. Hulstaert F, Blennow K, Ivanoiu A, Schoonderwaldt HC, Riemenschneider M, De Deyn PP et al. Improved discrimination of AD patients using $\beta$-amyloid(1-42) and tau levels in CSF. Neurology 52:1555-1562, 1999.

68. Maruyama M, Arai H, Sugita M, Tanji H, Higuchi M, Okamura $\mathrm{N}$ et al. Cerebrospinal fluid amyloid $\beta(1-42)$ levels in the mild cognitive impairment stage of Alzheimer's disease. Exp Neurol 172:433-436, 2001.

69. Sjögren M, Davidsson P, Gottfries J, Vanderstichele H, Edman A,
Vanmechelen E et al. The cerebrospinal fluid levels of tau, growth-associated protein-43 and soluble amyloid precursor protein correlate in Alzheimer's disease, reflecting a common pathophysiological process. Dement Geriatr Cogn Disord 12:257-264, 2001.

70. Sjögren M, Davidsson P, Tullberg M, Minthon L, Wallin A, Wikkelsö $\mathrm{C}$ et al. Both total and hyperphosphorylated tau are increased in Alzheimer's disease. J Neurol Neurosurg Psychiatry 70:624-630, 2001.

71. Buerger K, Zinkowski R, Teipel SJ, Tapiola T, Arai H, Blennow $\mathrm{K}$ et al. Differential diagnosis of Alzheimer's disease with cerebrospinal fluid levels of tau protein phosphorylated at threonine 231. Arch Neurol 59:1267-1272, 2002.

72. Riemenschneider M, Wagenpfeil S, Diehl J, Lautenschlager N, Theml T, Heldmann B et al. Tau and A $\beta 42$ protein in CSF of patients with frontotemporal degeneration. Neurology 58:16221628, 2002.

73. Shoji M, Matsubara E, Murakami T, Manabe Y, Abe K, Kanai M et al. Cerebrospinal fluid tau in dementia disorders: a large scale multicenter study by a Japanese study group. Neurobiol Aging 23:363-370, 2002.

74. Kapaki E, Paraskevas GP, Zalonis I, Zournas C. CSF tau protein and $\beta$-amyloid (1-42) in Alzheimer's disease diagnosis: discrimination from normal ageing and other dementias in the Greek population. Eur J Neurol 10:119-128, 2003.

75. Wallin A, Sjögren M, Davidsson P. Blennow K. Decreased cerebrospinal fluid acetylcholinesterase in patients with subcortical ischemic vascular dementia. Dement Geriatr Cogn Disord 16: 200-207, 2003

76. Kapaki E, Kilidireas K, Paraskevas GP, Michalopoulou M, Patsouris E. Highly increased CSF tau protein and decreased $\beta$-amyloid (1-42) in sporadic CJD: a discrimination from Alzheimer's disease? J Neurol Neurosurg Psychiatry 71:401-403, 2001.

77. Otto M, Wiltfang J, Cepek L, Neumann M, Mollenhauer B, Steinacker $\mathrm{P}$ et al. Tau protein and 14-3-3 protein in the differential diagnosis of Creutzfeldt-Jakob disease. Neurology 58:192197, 2002.

78. Van Everbroeck B, Green AJ, Vanmechelen E, Vanderstichele H, Pals P, Sanchez-Valle R et al. Phosphorylated tau in cerebrospinal fluid as a marker for Creutzfeldt-Jakob disease. J Neurol Neurosurg Psychiatry 73:79-81, 2002.

79. Green AJ. Use of 14-3-3 in the diagnosis of Creutzfeldt-Jakob disease. Biochem Soc Trans 30:382-386, 2002.

80. Jellinger KA. Diagnostic accuracy of Alzheimer's disease: a clinicopathological study. Acta Neuropathol 91:219-220, 1996.

81. Kosunen O, Soininen H, Paljärvi L, Heinonen O, Talasniemi S, Riekkinen PJ Sr. Diagnostic accuracy of Alzheimer's disease: a neuropathological study. Acta Neuropathol 91:185-193, 1996.

82. Takeda M, Tanaka T, Arai H, Sasaki H, Shoji M, Okamoto K. Basic and clinical studies on the measurement of $\beta$-amyloid(1-42) in cerebrospinal fluid as a diagnostic marker for Alzheimer's disease and related disorders: multicenter study in Japan. Psychogeriatrics 1:56-63, 2001.

83. Arai H, Morikawa Y, Higuchi M, Matsui T, Clark CM, Miura M et al. Cerebrospinal fluid tau levels in neurodegenerative diseases with distinct tau-related pathology. Biochem Biophys Res Commun 236:262-264, 1997.

84. Mecocci P, Cherubini A, Bregnocchi M, Chionne F, Cecchetti R, Lowenthal DT et al. Tau protein in cerebrospinal fluid: a new diagnostic and prognostic marker in Alzheimer disease? Alzheimer Dis Assoc Disord 12:211-214, 1998.

85. Molina L, Touchon J, Herpe M, Lefranc D, Duplan L, Cristol JP et al. Tau and apo E in CSF: potential aid for discriminating Alzheimer's disease from other dementias. NeuroReport 10:3491-3495, 1999.

86. Itoh N, Arai H, Urakami K, Ishiguro K, Ohno H, Hampel H et al. Large-scale, multicenter study of cerebrospinal fluid tau protein phosphorylated at serine 199 for the antemortem diagnosis of Alzheimer's disease. Ann Neurol 50:150-156, 2001.

87. Gomez-Tortosa E, Gonzalo I, Fanjul S, Sainz MJ, Cantarero S, Cemillan $\mathrm{C}$ et al. Cerebrospinal fluid markers in dementia with Lewy bodies compared with Alzheimer disease. Arch Neurol 60:1218-1222, 2003 
88. Kahle PJ, Jakowec M, Teipel SJ, Hampel H, Petzinger GM, Di Monte DA et al. Combined assessment of tau and neuronal thread protein in Alzheimer's disease CSF. Neurology 54:1498-1504, 2000.

89. Kanemaru K, Kameda N, Yamanouchi H. Decreased CSF amyloid $\beta 42$ and normal tau levels in dementia with Lewy bodies. Neurology 54:1875-1876, 2000.

90. Sáez-Valero J, Fodero LR, Sjögren M, Andreasen N, Amici S, Gallai V et al. Glycosylation of acetylcholinesterase and butyrylcholinesterase changes as a function of the duration of Alzheimer's disease. J Neurosci Res 72:520-526, 2003.

91. Morikawa Y, Arai H, Matsushita S, Kato M, Higuchi S, Miura M et al. Cerebrospinal fluid tau protein levels in demented and nondemented alcoholics. Alcohol Clin Exp Res 23:575-577, 1999.

92. Parnetti L, Lanari A, Amici S, Gallai V, Vanmechelen E, Hulstaert F. CSF phosphorylated tau is a possible marker for discriminating Alzheimer's disease from dementia with Lewy bodies. Phospho-tau International Study Group. Neurol Sci 22:77-78, 2001.

93. Hampel H, Buerger K, Zinkowski R, Teipel SJ, Andreasen N, Sjögren $\mathrm{M}$ et al. Measurement of phosphorylated tau epitopes in the differential diagnosis of Alzheimer's disease - a comparative study. Arch Gen Psychiatry 61:95-102, 2004.

94. Maddalena A, Papassotiropoulos A, Muller-Tillmanns B, Jung HH, Hegi T, Nitsch RM et al. Biochemical diagnosis of Alzheimer disease by measuring the cerebrospinal fluid ratio of phosphorylated tau protein to $\beta$-amyloid peptide42. Arch Neurol 60: 1202-1206, 2003.

95. Rosso SM, van Herpen E, Pijnenburg YA, Schoonenboom NS, Scheltens P, Heutink P et al. Total tau and phosphorylated tau 181 levels in the cerebrospinal fluid of patients with frontotemporal dementia due to P301L and G272V tau mutations. Arch Neurol 60:1209-1213, 2003.

96. Buerger K, Zinkowski R, Teipel SJ, Arai H, DeBernardis J, Kerkman D et al. Differentiation of geriatric major depression from Alzheimer's disease with CSF tau protein phosphorylated at threonine 231. Am J Psychiatry 160:376-379, 2003.

97. Rosler N, Wichart I, Jellinger KA. Clinical significance of neurobiochemical profiles in the lumbar cerebrospinal fluid of Alzheimer's disease patients. J Neural Transm 108:231-246, 2001.

98. Briani C, Ruggero S, Naccarato M, Cagnin A, Ricchieri GL, Pasqui $\mathrm{L}$ et al. Combined analysis of CSF $\beta$ A42 peptide and tau protein and serum antibodies to glycosaminoglycans in Alzheimer's disease: preliminary data. J Neural Transm 109:393-398, 2002.

99. Mulder C, Schoonenboom SN, Wahlund LO, Scheltens P, van Kamp GJ, Veerhuis R, Hack CE, Blomberg M, Schutgens RB, Eikelenboom P. CSF markers related to pathogenetic mechanisms in Alzheimer's disease. J Neural Transm 109:1491-1498, 2002.

100. Andreasen N, Minthon L, Vanmechelen E, Vanderstichele H, Davidsson P, Winblad B et al. CSF t-tau and CSF-A $\beta 42$ as predictors of development of Alzheimer's disease in patients with mild cognitive impairment. Neurosci Lett 273:5-8, 1999.

101. Andreasen N, Minthon L, Davidsson P, Vanmechelen E, Vanderstichele H, Winblad B. Evaluation of CSF-tau and CSF-A $\beta 42$ as diagnostic markers for Alzheimer's disease in clinical practice. Arch Neurol 58:373-379, 2001.

102. Andreasen N, Gottfries J, Vanmechelen E, Vanderstichele H, Davidsson P, Winblad B, Rosengren L, Blennow K. Evaluation of CSF biomarkers for axonal and neuronal degeneration, gliosis, and $\beta$-amyloid metabolism in Alzheimer's disease. J Neurol Neurosurg Psychiatry 71:557-558, 2001.

103. Riemenschneider M, Buch K, Schmolke M, Kurz A, Guder WG. Cerebrospinal protein tau is elevated in early Alzheimer's disease. Neurosci Lett 212:209-211, 1996.

104. Galasko D, Clark C, Chang L, Miller B, Green RC, Motter R et al. Assessment of CSF levels of tau protein in mildly demented patients with Alzheimer's disease. Neurology 48:632-635, 1997.

105. Galasko D, Chang L, Motter R, Clark CM, Kaye J, Knopman D et al. High cerebrospinal fluid tau and low amyloid $\beta 42$ levels in the clinical diagnosis of Alzheimer disease and relation to apolipoprotein E genotype. Arch Neurol 55:937-945, 1998.
106. Arai H, Ishiguro K, Ohno H, Moriyama M, Itoh N, Okamura N et al. CSF phosphorylated tau protein and mild cognitive impairment: a prospective study. Exp Neurol 166:201-203, 2000.

107. Gottfries J, Blennow K, Lehmann MW, Regland B, Gottfries CG. One-carbon metabolism and other biochemical correlate of cognitive impairment as visualized by principal component analysis. J Geriatr Psychiatry Neurol 14:109-114, 2001.

108. Lautenschlager NT, Riemenschneider M, Drzezga A. Primary degenerative mild cognitive impairment: study population, clinical, brain imaging and biochemical findings. Dement Geriatr Cogn Disord 12:379-386, 2001.

109. Riemenschneider M, Lautenschlager N, Wagenpfeil S, Diehl J, Drzezga A, Kurz A. Cerebrospinal fluid tau and $\beta$-amyloid 42 proteins identify Alzheimer disease in subjects with mild cognitive impairment. Arch Neurol 59:1729-1734, 2002.

110. Andreasen N, Vanmechelen E, Vanderstichele H, Davidsson P, Blennow K. Cerebrospinal fluid levels of total-tau, phospho-tau and A $\beta 42$ predicts development of Alzheimer's disease in patients with mild cognitive impairment. Acta Neurol Scand 107(Suppl 179):47-51, 2003

111. Arai H, Nakagawa T, Kosaka Y, Higuchi M, Matsui T, Okamura $\mathrm{N}$ et al. Elevated cerebrospinal fluid tau protein level as a predictor of dementia in memory-impaired patients. Alzheimer's Res 3:211-213, 1997.

112. Buerger K, Teipel SJ, Zinkowski R, Blennow K, Arai H, Engel R, Hofmann-Kiefer $\mathrm{K}$ et al. CSF tau protein phosphorylated at threonine 231 correlates with cognitive decline in MCI subjects. Neurology 59:627-629, 2002.

113. Skoog I, Davidsson P, Aevarsson O, Vanderstichele H, Vanmechelen $\mathrm{E}$, Blennow $\mathrm{K}$. Cerebrospinal fluid $\beta$-amyloid 42 is reduced before the onset of sporadic dementia: a populationbased study in 85-year-olds. Dement Geriatr Cogn Disord 15: 169-176, 2003.

114. Finley D, Varshavsky A. The ubiquitin system: functions and mechanisms. Trends Biochem Sci 10:343-347, 1985.

115. Herschko A, Ciechanover A. The ubiquitin pathway for the degradation of intracellular proteins. Prog Nucleic Acid Res Mol Biol 33:19-56, 1986.

116. Monia BP, Ecker DJ, Crooke ST. New perspectives on the structure and function of ubiquitin. Biotechnology 8:209-215, 1990.

117. Perry G, Friedman R, Shaw G, Chau V. Ubiquitin is detected in neurofibrillary tangles and senile plaque neurites of Alzheimer disease brains. Proc Natl Acad Sci USA 84:3033-3036, 1987.

118. Mori H, Kondo J, Ihara Y. Ubiquitin is a component of paired helical filaments in Alzheimer's disease. Science 235:1641-1644, 1987.

119. Wang GP, Khatoon S, Iqbal K, Grundke-Iqbal I. Brain ubiquitin is markedly elevated in Alzheimer disease. Brain Res 566:146$151,1991$.

120. Wang GP, Grundke-Iqbal I, Kascsak RJ, Iqbal K, Wisniewski HM. Alzheimer neurofibrillary tangles: monoclonal antibodies to inherent antigen(s). Acta Neuropathol (Berl) 62:268-275, 1984.

121. Mehta PD, Thal L, Wisniewski HM, Grundke-Iqbal I, Iqbal K. Paired helical filament antigen in CSF. Lancet 2:35, 1985.

122. Perry G, Mulvihill P, Fried VA, Smith HT, Grundke-Iqbal I, Iqbal K. Immunochemical properties of ubiquitin conjugates in the paired helical filaments of Alzheimer disease. J Neurochem 52: 1523-1528, 1989.

123. Wang GP, Iqbal K, Bucht G, Winblad B, Wisniewski HM, Grundke-Iqbal I. Alzheimer's disease: paired helical filament immunoreactivity in cerebrospinal fluid. Acta Neuropathol (Berl) 82:6-12, 1991 .

124. Kudo T, Iqbal K, Ravid R, Swaab DF, Grundke-Iqbal I. Alzheimer disease: correlation of cerebrospinal fluid and brain ubiquitin levels. Brain Res 639:1-7, 1994.

125. Blennow K, Davidsson P, Wallin A, Gottfries CG, Svennerholm L. Ubiquitin in cerebrospinal fluid in Alzheimer's disease and vascular dementia. Int Psychogeriatr 6:13-22, 1994.

126. Friede RL, Samorajski T. Axon caliber related to neurofilaments and microtubules in sciatic nerve fibers of rats and mice. Anat Rec 167:379-387, 1970.

127. Sjogren M, Blomberg M, Jonsson M, Wahlund LO, Edman A, Lind K, Rosengren L, Blennow K, Wallin A. Neurofilament 
protein in cerebrospinal fluid: a marker of white matter changes. J Neurosci Res 66:510-516, 2001.

128. Rosengren LE, Karlsson JE, Sjogren M, Blennow K, Wallin A. Neurofilament protein levels in CSF are increased in dementia. Neurology 52:1090-1093, 1999.

129. Sjogren M, Rosengren L, Minthon L, Davidsson P, Blennow K, Wallin A. Cytoskeleton proteins in CSF distinguish frontotemporal dementia from AD. Neurology 54:1960-1964, 2000.

130. Hu YY, He SS, Wang XC, Duan QH, Khatoon S, Iqbal K, Grundke-Iqbal I, Wang JZ. Elevated levels of phosphorylated neurofilament proteins in cerebrospinal fluid of Alzheimer disease patients. Neurosci Lett 320:156-160, 2002.

131. Nixon RA. The regulation of neurofilament protein dynamics by phosphorylation: clues to neurofibrillary pathobiology. Brain Pathol 3:29-38, 1993.

132. Benowitz LI, Shashoua VE, Yoon M. Specific changes in rapidly transported proteins during regeneration of goldfish optic nerve. J Neurosci 1:300-307, 1981.

133. Benowitz LI, Perrone-Bizzozero NI, Finklestein SP, Bird ED. Localization of the growth-associated phosphoprotein GAP-43 (B-50, F1) in the human cerebral cortex. $J$ Neurosci 9:990-995, 1989.

134. Mercken M, Lübke U, Vandermeeren M, Gheuens J, Oestreicher AB. Immunocytochemical detection of the growth-associated protein B-50 by newly characterized monoclonal antibodies in human brain and muscle. J Neurobiol 23:309-321, 1992.

135. Masliah E, Mallory M, Hansen L, Alford M, Albright T, DeTeresa R, Terry R, Baudier J, Saitoh T. Patterns of aberrant sprouting in Alzheimer's disease. Neuron 6:729-739, 1991.

136. Bogdanovic N, Davidsson P, Volkmann I, Winblad B, Blennow $\mathrm{K}$. Growth-associated protein GAP-43 in the frontal cortex and in the hippocampus in Alzheimer's disease: an immunohistochemical and quantitative study. J Neural Transm 107:463-478, 2000.

137. Davidsson P, Blennow K. Neurochemical dissection of synaptic pathology in Alzheimer's disease. Int Psychogeriatr 10:11-23, 1998.

138. Masliah E, Mallory M, Alford M, DeTeresa R, Hansen LA, McKeel DW Jr et al. Altered expression of synaptic proteins occurs early during progression of Alzheimer's disease. Neurology $56: 127-129,2001$.

139. Davidsson P, Punchades M, Blennow K. Identification of synaptic vesicle, pre- and postsynaptic proteins in human cerebrospinal fluid using liquid phase isoelectric focusing. Electrophoresis 20: 431-437, 1999.

140. Vanmechelen E, Blennow K, Davidsson P, Cras P, Van de Voorde A. Combination of tau/phospho-tau with other biochemical markers for Alzheimer CSF diagnosis and tau in CSF as marker for neurodegeneration. In: Alzheimer's disease: biology, diagnosis and therapeutics (Iqbal K, Winblad B, Nishimura T, Takeda M, Wisniewski HM, eds), pp 197-203. Chichester, UK: Wiley Ltd., 1997.

141. Ozturk M, de la Monte S, Gross J, Wands JR. Elevated levels of an exocrine pancreatic secretory protein in Alzheimer disease brain. Proc Natl Acad Sci USA 86:419-423, 1989.

142. De la Monte SM, Wands JR. Neuronal thread protein overexpression in brains with Alzheimer's disease lesions. J Neurol Sci 113:152-164, 1992

143. De la Monte SM, Ozturk M, Wands JR. Enhanced expression of an exocrine pancreatic protein in Alzheimer's disease and the developing human brain. J Clin Invest 86:10004-10013, 1990.

144. De la Monte SM, Volicer L, Hauser SL, Wands JR. Increased levels of neuronal thread protein in cerebrospinal fluid of patients with Alzheimer's disease. Ann Neurol 32:733-742, 1992.

145. Gross J, Carlson RI, Brauer AW, Margolies MN, Warshaw AL, Wands JR. Isolation, characterization, and distribution of an unusual pancreatic human secretory protein. $J$ Clin Invest 76:21152126, 1985.

146. Blennow K, Wallin A, Chong JK. Cerebrospinal fluid "neuronal thread protein" comes from serum by passage over the bloodbrain barrier. Neurodegeneration 4:187-193, 1995.

147. Monte SM, Ghanbari K, Frey WH, Beheshti I, Averback P, Hauser SL et al. Characterization of the AD7C-NTP cDNA expression in Alzheimer's disease and measurement of a 41-kD protein in cerebrospinal fluid. J Clin Invest 100:3093-3104, 1997.

148. Ghanbari K, Ghanbari H. A sandwich enzyme immunoassay for measuring AD7C-NTP as an Alzheimer's disease marker: AD7C test. J Clin Lab Anal 12:223-226, 1998. 